\title{
THE MOVEMENT FOR RESPONSIBLE COUNTY GOVERNMENT
}

\author{
By H. S. Gilberertson,
}

Executive Secretary, National Short Ballot Organization, New York City.

County government in every state, except Rhode Island and Connecticut (which have troubles of their own), whether it be under the town system or under the commissioner system, is organized on the plan of making as many officers as possible "directly responsible to the people." The people elect their board of supervisors or commissioners, as the case may be, and undertake to hold them responsible for the financial affairs of the county. They are to control, if they can, the expenditures, among others, of the sheriff. But always the sheriff is no subordinate of theirs; the people selected him! In the course of his work he collects sundry fees which so far as the supervisors are concerned he may account for or not as he pleases. They may reach him in some slow roundabout way but never by the direct power of summary removal which a private business concern may exercise. The supervisors may set out upon a program of economy and efficiency including, let us say, the standardization of supplies. But the county clerk will not recognize their superior authority; he will run his office to suit his personal convenience; and if the supervisors undertake to check him he may find some way of appealing to the people. The superintendent of the poor, the treasurer and the auditor may likewise go their respective gaits, and the county will be blessed not with one government, but with several.

This is the particular form which the ancient and revered theory of the separation of powers has taken in this branch of government. No one officer or board is entrusted with power enough to do serious wrong; let the people be the boss!

Noble sentiment. But there is a reverse side to it. Division of power carries with it division of responsibility. It is as though the board of directors were charged with the control of a private enterprise, but were expressly denied the power to select the manager and heads of departments wherewith to execute their trust. So 
vital to their civic happiness have the people regarded this disjointedness of the county that many of the constitutions are explicit as to which officers shall be elected and in not a few cases name the whole list.

\section{The Headlessness of Counties}

The county is about the only human institution that is absolutely headless. There are, of course, some exceptions. In the first class counties of New Jersey (Hudson and Essex), the state has provided for an officer elected by the people who has the title of "supervisor" and exercises powers similar to those of the mayor of a city. He makes no appointments, but he may suspend and remove subordinates, veto appropriations and make recommendations. In Cook County (Chicago), Ill., a president of the board of supervisors is elected by the people. Kings County (Brooklyn), N. Y., before consolidation had a "supervisor-at-large." But none of these exceptional executives has powers at all comparable to those of the mayor of New York or Cleveland. In the general run of counties the chief executive is not a single officer but the governing body itself. But almost invariably this body serves on part time and only meets at intervals, of sometimes as much as a month. If the town plan is in use the board may be very large as in Westchester County, N. Y., where the number of supervisors is forty-one or in Erie where there are forty-one members. That such a board would be all but strangers, of their own knowledge, to the detailed needs of the various offices in the county, goes without saying.

No, the ingenious Anglo-Saxon mind has discovered a substitute for direct personal supervision. This government of ours, we are told, is a "government of laws, not of men." If a given officer goes wrong or if he neglects his duties, then the supervisors are authorized to go to the district attorney and get him to take action on the officer's bond or to institute a criminal prosecution. If the district attorney is negligent in the matter, the supervisors may go to the governor with charges of neglect of duty against him. If the original officer in question is just plain lazy, slow or inefficient, then everybody simply has to wait "till he gets round to it."

All this circumambulation forsooth, in the name of democracy! It actually fulfils the conception of popular rule for no inconsiderable body of superficial political thinkers. Where the system goes 
wrong, they inject a little more confusion, a little more irresponsibility into the plan of government-" the cure for democracy is more democracy." Even the reform of county government is conceived in the spirit of negation. Americans have a way when things go badly in the government, of trimming somebody's wings, of setting up "checks and balances." But every time they reduce an officer's power they have not only prevented him from rising to heights of constructive effort, but they have actually so obscured his responsibility as to increase the probability of his going wrong.

But to leave off the criticism of the county and to proceed to constructive remedies, what measures may be proposed?

\section{What Responsibility means in County Reconstruction}

In the approach toward an ideal county government the principle which underlies every accredited political reform must dominate: the principle of responsibility. The central state government must assume greater responsibility for the local execution of its own mandates. The locality must take full charge of its local affairs, in pursuance of the principle of home rule (which is but a phase of responsibility). The responsibility of the county electorate must be fixed by making the conditions of citizenship simple and workable. In plain English, every factor in government must be assigned its own proper function and must be put in possession of the means wherewith to enforce the trust imposed upon it.

With this standard in mind the form of a more perfect county government will not be difficult to conceive. Under a system of home rule the county will have been brought face to face with its obligation to frame its local policies. A suitable local legislature or governing body will have to be erected to represent accurately the people of the county. If the several localities in the county possess an identity which justifies their having a distinct voice in the governing body, they will be taken care of. But if on the other hand the fact is that the county is a geographical and social unit, the form of the governing body will reflect that condition. If the county consists of mixed urban and rural elements, that condition will not be overlooked. And cases will come to mind also where the county is identical with a city, in which case the county may utilize the governing body at hand.

Toward county unity and simplified governing bodies, New 
Jersey has also contributed a strong impetus to the popularity of the small board. In 1902 the legislature passed the so-called Strong Act under which any county might abandon the idea of district representation. Thereafter the people of the county as a whole elect (according to the population of the county) from three to nine freeholders. This system has been adopted (up to 1915) in most of the twenty-one counties.

\section{Responsible County Legislature}

The county legislature, in keeping with its amplified powers, its greater dignity and conspicuousness, will have a corresponding control over its agencies. It will not be obliged to carry out its trust through subordinates not of its own selection. Nor will it scatter its own powers of control, but will constitute some one person the head of the county administration. And it will protect its own responsibility by selecting for the executive headship a person not qualified by reason of partisan political experience but of specific fitness for performing his official duties.

The executive in his turn will have ample powers of control, through appointment and otherwise, of the county officers, at least in the "business" as distinguished from the "judicial" establishment of the county.

His powers will not be limited as are those of the supervisor, an office which has been established in counties of the first class (Hudson and Essex). These are apparently the only counties in the country which are operated under the slightest semblance of a single executive head. The executive is elected by the people and is in fact a survival from the time when the board of chosen freeholders (supervisors) were elected from districts, with a view to unifying the interests of the several localities, somewhat after the fashion of a mayor of a city. He is required "to be vigilant and active in causing the laws and ordinances of the county to be executed and enforced." Subject to the civil service law he has power to suspend and remove but not to appoint subordinates. He may propose legislation and veto resolutions.

And the state itself will sometime look more carefully and concernedly to the enforcement of its own laws. It will frankly do one of two things: either it will decide that a given law deals with really local questions, in which case it will wipe it off the statutes and 
leave them to be handled by the county legislature; or else, it will resolve to see that the law, if wise, is properly enforced, and will proceed to establish its own means for its enforcement.

And finally, the responsibilities of citizenship will be conserved. No voter will be called upon to make selections from long lists of obscure minor officers, whom he never sees and whose duties he knows little or nothing about. He will have the assurance that by watching and controlling one set of officers he will control the whole county establishment.

\section{A Concrete Proposal}

A proposal that practically squares with this formula was put forth some years ago by a group of Oregon citizens under the leadership of W. S. U'Ren in a projected amendment to the state constitution. The county business would be in the hands of a board of three directors to be elected by the voters of the county for terms of six years. This board would have power to "make all expedient rules and regulations for the successful, efficient and economic management of all county business and property." It would be required, however, to employ a business manager who would be the "chief executive of the county," -and the choice would not be limited to the state of Oregon. The salary of this officer would be determined by the board. With him would rest the appointment of the subordinate county officers, except that the board should be empowered to audit bills, either directly or through an auditor.

The skeleton of the proposed Oregon system is similar to that of the commission manager plan of city government which has been in successful operation for several years in Dayton and Springfield, Ohio, Cadillac and Manistee, Michigan, and about thirty other cities of various sizes and is growing rapidly in public favor. A more complete and detailed scheme based upon the identical principles was embodied in a bill introduced in the New York legislature of 1915 by the New York Short Ballot Organization.

\section{Some Practical Contributions to Responsible County Goverment}

In actual life no county has taken longer steps to secure a simplified structure than Los Angeles, California, which was the first county to act under the home rule amendment. This charter 
starts out by abandoning the theory that every county officer must be elected. The supervisors are retained on the "ticket," but county superintendent of schools, coroner, public administrator, county clerk, treasurer, tax collector, recorder and surveyor, all of whom were formerly elected by the voters, are now appointed by and responsible to the county legislature, which is the board of supervisors. The sheriff, the auditor, the assessor and the district attorney are still elective. In thus extending the power of supervisors, the charter framers require that, with a few exceptions, the officers shall be chosen from competitive lists on the basis of merit and fitness. The fee system is abolished.

The charter of San Bernardino County, California, adopted shortly after the one in Los Angeles, provided for a board of five supervisors elected at large, one at a time, this board to appoint all other county officers except judges. But the changes seemed so radical that the people amended the charter out of all semblance to its original conception, before it was ever put into operation.

For the immediate future the movement for better county government must be mainly to bring the voters to see that there is a "county problem" of no small importance. No division of government contributes so largely to the continuance of political machines-the county is ideally constructed for that. The three thousand counties in the United States now spend annually about half as much as the federal government-a hint to the taxpayer. Social workers are aware that the management of the local welfare functions are often administered by counties in a manner that is nothing short of barbarous. But the county problem will not be solved by hitting at particular evil symptoms. We shall, in the writer's opinion, eradicate all the more serious evils by applying all along the line and to the practical limit the reconstructive principle of responsibility which is theme and subject of this volume. 